\title{
DISINFECTION OF GUTTA-PERCHA CONES WITH CHLORHEXIDINE
}

\author{
Roberta Redmerski ${ }^{1}$; Joice Renata Bulla ${ }^{1}$; Tatiana Moreno ${ }^{1}$; Lourdes Botelho Garcia ${ }^{2}$; \\ Celso Luiz Cardoso ${ }^{2 *}$
}

${ }^{1}$ Departamentos de Odontologia, Universidade Estadual de Maringá, Maringá, PR, Brasil; 2 Departamento de Análises Clínicas, Universidade Estadual de Maringá, Maringá, PR, Brasil

Submitted: February 02, 2007; Returned to authors for corrections: July 01, 2007; Approved: September 26, 2007.

\begin{abstract}
This study investigated the effectiveness of detergent and aqueous solutions of $2 \%$ chlorhexidine digluconate in decontaminating gutta-percha cones (gpc) contaminated with bacteria, yeast, or bacterial spores. Guttapercha cones were contaminated with $10^{7}-10^{8}$ colony-forming units per milliliter $(\mathrm{cfu} / \mathrm{ml})$ of the following test organisms: Staphylococcus aureus, Enterococcus faecalis, Escherichia coli, or Candida albicans. Spores of Bacillus subtilis were also tested. Contaminated gpc were treated with the chlorhexidine solutions for 1, 5, 10 , or $15 \mathrm{~min}$. Each cone was then transferred to a tube containing saline and the micoorganisms were recovered after homogenization for cfu determination. Both detergent and aqueous chlorhexidine solutions were effective in eliminating $S$. aureus, E. faecalis, and C. albicans cells adhered on the surface of gpc within $1 \mathrm{~min}$ of exposure. E. coli was eliminated in $5 \mathrm{~min}$ with detergent solution. The Bacillus subtilis spores were eliminated by chlorhexidine solutions within $5 \mathrm{~min}$. The results of this study demonstrated that both aqueous and detergent solutions of $2 \%$ chlorhexidine digluconate were effective in decontaminating gpc within 5 minutes of exposure.
\end{abstract}

Key words: Chlorhexidine, decontamination, gutta-percha cones

\section{INTRODUCTION}

In endodontic practice, the elimination or significant reduction of microorganisms from the root canal by chemomechanical preparation is an essential factor in successful treatment. Care must be taken during this procedure to prevent contamination of instruments and filling materials, to avoid root canal cross-infection $(7,9,18,29,31,37)$.

Gutta-percha cones (gpc) with supplementary cement are now widely used to fill root canals (18). However, gpc have the disadvantage of not resisting conventional heat sterilization. For this reason, although gpc are sold commercially in sealed packages, they may be contaminated $(14,17,24)$. Contamination of gpc may also occur during the endodontic procedure (33). Thus, in order not to break the antisseptic chain in endodontic therapy, gpc require rapid chairside decontamination before use $(7,9,12,18,29)$.

Several tests were used to observe the antimicrobial activity of chemical decontaminants of gpc, but there is no consensus for the best method (4-6,10,12,19,23,29,31,33,35).

Chlorhexidine is widely used in dentistry because of its broad spectrum of antimicrobial activity (21). However, its effectiveness in decontaminating gpc has been found to differ in some studies $(6,14,31,33,35)$. In order to better investigate this matter, we carried out a quantitative microbiological study to investigate the antimicrobial activity of $2 \%$ chlorhexidine digluconate detergent solution, using as an experimental model gpc contaminated with bacterial cells (Staphylococcus aureus, Escherichia coli, Enterococcus faecalis), yeast (Candida albicans), or bacterial spores (Bacillus subtilis).

*Corresponding Author. Mailing address: Laboratório de Microbiologia (Sala 116, Bloco I-90), Departamento de Análises Clínicas. Universidade Estadual de Maringá. Av. Colombo 5790, Campus Universitário, CEP 87020-900 Maringá, PR, Brasil. Fone: +55 44 3261-4953, Fax: +55 44 32614860. E-mail: clcardoso@uem.br 


\section{MATERIALS AND METHODS}

\section{Test microorganisms}

Test microorganisms obtained from the American Type Culture Collection (ATCC) (Rockville, MD, USA), included the following strains: Staphylococcus aureus ATCC 6538 (Experiment 1), (ii) Enterococcus faecalis ATCC 29212 (Experiment 2), (iii) Escherichia coli ATCC 25922 (Experiment 3), (iv) Candida albicans ATCC 90028 (Experiment 4), and Bacillus subtilis ATCC 6633 spore suspension (Experiment 5).

\section{Inocula}

(i) Experiments 1 to 3: overnight cultures in tryptic soy broth (Difco Laboratories, Sparks, MD, USA) containing about $10^{8}$ to $10^{9}$ colony-form units per milliliter $(\mathrm{CFU} / \mathrm{ml})$ were used to contaminate gutta-percha cones; (ii) Experiment 4: the inoculum was an overnight culture in Sabouraud dextrose broth (Difco) containing approximately $10^{7} \mathrm{CFU} / \mathrm{ml}$; (iii) Experiment 5: a Bacillus subtilis spore suspension containing about $10^{7}$ spores $/ \mathrm{ml}$, prepared as described by Stella (34), was used as the inoculum. Briefly, broth cultures from $24 \mathrm{~h}$ of $B$. subtilis were inoculated in Roux bottles containing $250 \mathrm{ml}$ of modified sporulation agar (34), and incubated at $37^{\circ} \mathrm{C}$. The sporulation grade was observed by Gram stain. After 12 to 15 days, the spores were removed with cold sterile distilled water, centrifuged at $4^{\circ} \mathrm{C}$ for $20 \mathrm{~min}$ at 3,000 $\mathrm{rpm}$, washed with saline twice, and ressuspended in sterile distilled water to give about $10^{7}$ to $10^{8} \mathrm{cfu} / \mathrm{ml}$.

\section{Gutta-percha cones}

The following brands of gpc were used: (i) Dentsply \#80 (Dentsply Indústria e Comércio Ltda., Petrópolis, Rio de Janeiro, Brazil); (ii) Hygenic \#80 (Hygenic Corporation, Akron, OH, USA). The gpc were decontaminated by immersion for 30 minutes in $5 \%$ sodium hypochlorite solution. Next, the cones were individually and aseptically rinsed in sterile distilled water, and allowed to dry in sterile $100 \times 15 \mathrm{~mm}$ Petri dishes containing sterile filter-paper pads.

\section{Chlorhexidine solutions}

The following chlorhexidine solutions were used: (i) $2 \%$ chlorhexidine digluconate antiseptic-detergent solution containing 2\% ethyl alcohol (Glicolabor Indústria Farmacêutica Ltda., Ribeirão Preto, SP, Brazil); (ii) $2 \%$ chlorhexidine digluconate aqueous solution (Laboratório Enila - Indústria e Comércio de Produtos Químicos e Farmacêuticos S/A, Rio de Janeiro, RJ, Brazil).

\section{Viable counts of inocula}

Viable counts of inocula were performed by the drop-plate technique described by Miles et al. (22), modified as follows. Briefly, 10-fold dilutions of each inoculum were prepared, $0.2 \mathrm{ml}$ being added to $1.8 \mathrm{ml}$ of sterile saline solution containing the following neutralizers: $0.5 \%$ Tween 80 (Difco) and $0.07 \%$ lecithin (Santista Alimentos S.A., Ponta Grossa, PR, Brazil) $(1,26,31)$ in experiments 1 to 4 , and without neutralizers in experiment 5 . Three $0.02 \mathrm{ml}$ drops of $10^{-4}$ to $10^{-7}$ dilutions were applied to each quadrant of $100 \times 15 \mathrm{~mm}$ Petri plates containing tryptic soy agar (Difco) in experiments 1 to 3 and 5, and Sabouraud modified agar in experiment 4 . After drying of the inoculum, the plates were incubated at $37^{\circ} \mathrm{C}$ for 24 to 48 hours. The number of colonies selected for counting was estimated from the arithmetic mean of three counts from the same dilution that showed the largest numbers of colonies without signs of confluence or gross diminution in colony size as a result of overgrowth (21).

\section{Contamination of gpc}

Twenty gpc, previously decontaminated with $5 \%$ sodium hypochlorite, were fully immersed for 30 minutes in a sterile Petri dish containing $20 \mathrm{ml}$ of the respective inocula (about $10^{8}$ $\mathrm{CFU} / \mathrm{ml}$ ). Next, the cones were aseptically transferred to sterile Petri dishes containing sterile filter-paper pads, and allowed to air-dry for 5 to 10 minutes at room temperature.

\section{Antimicrobial evaluation}

For each experiment, a series of 16 contaminated gpc $(8$ cones of each brand) was used. Duplicate cones were aseptically transferred individually to sterile $13 \times 100 \mathrm{~mm}$ tubes containing $3 \mathrm{ml}$ of the chlorhexidine solution and treated for 1, 5, 10, or 15 minutes. Next, each cone was aseptically transferred to a $13 \mathrm{x}$ $100 \mathrm{~mm}$ tube containing $3 \mathrm{ml}$ of sterile saline solution with neutralizers - $0.5 \%$ Tween 80 (Difco) and $0.07 \%$ lecithin (Alimentos Santista S.A.) - to prevent carryover inhibition in experiments 1 to $4(1,26,31)$, or to a $16 \times 160 \mathrm{~mm}$ tube containing $10 \mathrm{ml}$ of sterile saline solution (without neutralizers) in experiment 5 (8), for microbiological assay. The solution was mixed for 30 seconds with a vortex shaker (Thermolyne, model M63215, Barnstead/Thermolyne Corporation, Dubuque, IA, USA) to remove the surviving microorganisms. The suspension was diluted from $10^{0}$ to $10^{-3}$ and tested for the drop-plate technique (22).

\section{Antimicrobial evaluation controls}

For each experiment the following controls were carried out: (i) Positive control: a procedure identical to the test was used, except that the chlorhexidine solution was replaced by a sterile saline solution with neutralizers in experiments 1 to 4 , and without neutralizers in experiment 5; (ii) Negative control: a series of four previously decontaminated cones (two cones of each brand) was used. Each cone was transferred to $13 \times 100 \mathrm{~mm}$ tubes containing $3 \mathrm{ml}$ of sterile saline solution. After 15 minutes of contact, the cone set was mixed for 30 seconds with a vortex shaker (Thermolyne), and volumes of $1 \mathrm{ml}$ of each sample was plated by the pour-plate technique using tryptic soy agar (Difco) (experiments 1-3 and 5) or Sabouraud modified agar (Difco) 
(experiment 4); (iii) Mechanical removal control: in each experiment, for each chlorhexidine solution tested, viable counts were done, in duplicate, by the drop-plate technique, of the sampling fluid that remained in the $13 \times 100 \mathrm{~mm}$ tubes from the tests and positive controls after the cones were removed. These counts represent the number of microorganisms or spores mechanically removed from the cones after treatment with saline solution (positive control) or chlorhexidine (test); (iv) Carryover control: the carryover control was performed according to Frank \& Pelleu (12). Briefly, a contaminated cone and an uncontaminated cone previously treated for 15 minutes with one of the tested chlorhexidine solutions were aseptically transferred to a $13 \times 100 \mathrm{~mm}$ tube containing $3 \mathrm{ml}$ of sterile saline solution with neutralizers - 0.5\% Tween 80 (Difco) and $0.07 \%$ lecithin (Santista Alimentos S.A.) - in experiments 1 to $4(1,26,31)$, and to a $16 \times 160 \mathrm{~mm}$ tube containing $10 \mathrm{ml}$ of sterile saline solution without neutralizers in experiment 5 (8). Next, the material was mixed for 30 seconds with a vortex shaker (Thermolyne), and viable counts of dilutions $10^{\circ}$ to $10^{-3}$ of this sample fluid was performed by the drop-plate technique (22). In parallel as a control, an identical procedure was performed, except that only a contaminated cone was placed into a tube containing sterile saline solution with or without neutralizers (12). Comparison between the number of recovered microorganisms from the carryover and control tubes was performed by Student's $t$ test for independent samples, using the program Statistica for Windows (version 6.0, 2001; StatSoft, Inc., Tulsa, OK, USA). A value of $P 0.05$ was considered significant.

\section{RESULTS}

Table 1 shows that both detergent and aqueous $2 \%$ chlorhexidine solutions were effective in eliminating S. aureus, E. faecalis, and C. albicans cells adhered on the surface of gpc after $1 \mathrm{~min}$ of exposure. E. coli was eliminated with detergent solution in $5 \mathrm{~min}$. The Bacillus subtilis spores were eliminated within 5 minutes. Antimicrobial effectiveness of chlorhexidine solutions was the same in both brands of the gutta-percha cones (Table 1).

The real contamination load of gpc was estimated by the number of tested microorganisms recovered from the gpc: $S$. aureus $(2,000000 \pm 1,000000 \mathrm{cfu})$, E. faecalis $(1,100000 \pm 480$ $000 \mathrm{cfu})$, E. coli $(5,000000 \pm 2,400000 \mathrm{cfu}), C$. albicans $(1100 \pm$ $560 \mathrm{cfu})$, and B. subtilis spores (16000 $\pm 5600 \mathrm{cfu}$ ) (Table 1).

In relation to the mechanical removal controls, no test microorganism was recovered from sampling fluid that remained either in the $13 \times 100 \mathrm{~mm}$ (experiments 1-4) or $16 \times 160 \mathrm{~mm}$ (experiment 5) test tubes after the cones were removed. The mean $( \pm$ SD) of the number of recovered microorganisms from the control tubes was $160000 \pm 70000 \mathrm{cfu} /$ cone (S. aureus), 200 $000 \pm 81000 \mathrm{cfu} /$ cone (E. faecalis), $610000 \pm 410000 \mathrm{cfu} /$ cone
(E. coli), $18000 \pm 16000 \mathrm{cfu} / \mathrm{cone}$ (C. albicans), and $1800 \pm 2$ $100 \mathrm{cfu} /$ cone (B. subtilis spores).

The effect of chlorhexidine carryover into the assay media on recovery of S. aureus, E. faecalis, E. coli, and C. albicans cells (neutralization method), and $B$. subtilis spores (dilution method) is shown in Table 2. There were no significant differences between the number of viable cells or spores recovered from the control and carryover test tubes $(P>0.05)$.

All 16 sterile gutta-percha cones used as negative controls showed no microbial growth.

\section{DISCUSSION}

Chlorhexidine, because of its broad spectrum of antimicrobial activity, substantivity, and hypoallergenic property is probably the biocide most used in the formulation of antiseptics, particularly those destined for hand washing and antisepsis of the oral cavity (21). Despite its pronounced bactericidal activity (27), chlorhexidine does not kill bacterial spores, i.e., it is not sporicidal $(21,28,30)$. However, chlorhexidine prevents development of bacterial spores by inhibiting spore outgrowth (21). In our study, probably this sporostatic activity of chlorhexidine was responsible for inhibition of the development of spores recovered from gpc treated for 5 min with the chlorhexidine solutions (Table 1).

Our results demonstrated that both aqueous and detergent solutions of $2 \%$ digluconate chlorhexidine were effective in decontaminating gpc within $5 \mathrm{~min}$. However, it is worth pointing out that after 1 min of contact, detergent chlorhexidine was less effective than aqueous chlorhexidine in eliminating E. coli cells adhered on the surface of gpc (Table 1). This finding can possibly be explained by the formulation-dependence of the chlorhexidine, i.e., chlorhexidine preparations with the same concentration of the active ingredient (chlorhexidine digluconate) can differ in their antimicrobial activity due to differences in chlorhexidine preparations from different manufacturers $(3,16)$.

In our study, except for $C$. albicans, the real load of the contamination of the cones was very close to the total load of contamination. The mechanical removal of the controls, i.e., the detachment of the test microorganisms adhered on the surface of contaminated cones after immersion in the saline, was 7.27\% (S. aureus), $10.89 \%$ (E. coli), $15.38 \%$ (E. faecalis), $27.27 \%$ (spores of B. subtilis), and $90.58 \%$ (C. albicans) of the total load of contamination. This indicated that the experimental contaminations was consistent with the amount of the microorganisms recovered from gpc.

The results of our study are consistent with those reported in other qualitative microbiological studies $(6,33,35)$. Suchde $e t$ al. (35) showed the effectiveness of a $1.5 \%$ chlorhexidine gluconate detergent solution (Savlon $®$ ) in decontaminating gpc in 30 seconds. They used stock cultures of staphylococci, 
Table 1. Microbial recovery of gpc contaminated with Staphylococcus aureus, Enterococcus faecalis, Escherichia coli, or Candida albicans cells and Bacillus subtilis spores.

\begin{tabular}{|c|c|c|c|c|c|c|c|c|}
\hline \multirow{3}{*}{ Microorganisms } & \multicolumn{4}{|c|}{$\begin{array}{c}\text { Aqueous solution of } 2 \% \text { chlorhexidine } \\
\text { Gutta-Percha Cones }\end{array}$} & \multicolumn{4}{|c|}{$\begin{array}{l}\text { Detergent solution of } 2 \% \text { chlorhexidine } \\
\text { Gutta-Percha Cones }\end{array}$} \\
\hline & \multicolumn{2}{|c|}{ Dentsply® } & \multicolumn{2}{|c|}{ Hygenic ${ }^{\circledR}$} & \multicolumn{2}{|c|}{ Dentsply® } & \multicolumn{2}{|c|}{ Hygenic ${ }^{\circledR}$} \\
\hline & $\mathrm{TE}^{\dagger}$ & $\mathrm{PC}^{*}$ & $\mathrm{TE}$ & $\mathrm{PC}$ & $\mathrm{TE}$ & $\mathrm{PC}$ & $\mathrm{TE}$ & $\mathrm{PC}$ \\
\hline \multicolumn{9}{|l|}{$\begin{array}{c}\text { S. aureus } \\
\text { (ATCC 6538) }\end{array}$} \\
\hline $1 \mathrm{~min} *$ & $(-)^{\S}$ & 6.09 & $(-)$ & 5.52 & $(-)$ & 6.04 & $(-)$ & 5.63 \\
\hline $5 \mathrm{~min}$ & $(-)$ & 5.86 & $(-)$ & 5.52 & $(-)$ & 6.00 & $(-)$ & 5.58 \\
\hline $10 \mathrm{~min}$ & $(-)$ & 5.95 & $(-)$ & 5.69 & $(-)$ & 6.05 & $(-)$ & 5.48 \\
\hline $15 \mathrm{~min}$ & $(-)$ & 5.82 & $(-)$ & 5.41 & $(-)$ & 5.94 & $(-)$ & 5.58 \\
\hline \multicolumn{9}{|l|}{$\begin{array}{l}\text { E. faecalis } \\
\text { (ATCC 29212) }\end{array}$} \\
\hline $1 \mathrm{~min}$ & $(-)$ & 5.42 & $(-)$ & 5.73 & $(-)$ & 5.71 & $(-)$ & 5.46 \\
\hline $5 \min$ & $(-)$ & 5.54 & $(-)$ & 5.77 & $(-)$ & 5.71 & $(-)$ & 5.65 \\
\hline $10 \mathrm{~min}$ & $(-)$ & 5.31 & $(-)$ & 5.70 & $(-)$ & 5.36 & $(-)$ & 5.63 \\
\hline $15 \mathrm{~min}$ & $(-)$ & 5.62 & $(-)$ & 4.96 & $(-)$ & 5.43 & $(-)$ & 4.90 \\
\hline \multicolumn{9}{|l|}{$\begin{array}{c}\text { E. coli } \\
\text { (ATCC } 25922)\end{array}$} \\
\hline $1 \mathrm{~min}$ & $(-)$ & 6.18 & $(-)$ & 6.00 & 4.82 & 6.16 & 4.95 & 6.06 \\
\hline $5 \min$ & $(-)$ & 6.52 & $(-)$ & 6.15 & $(-)$ & 6.20 & $(-)$ & 6.55 \\
\hline $10 \mathrm{~min}$ & $(-)$ & 5.95 & $(-)$ & 6.11 & $(-)$ & 6.20 & $(-)$ & 6.27 \\
\hline $15 \mathrm{~min}$ & $(-)$ & 5.93 & $(-)$ & 6.08 & $(-)$ & 6.37 & $(-)$ & 6.27 \\
\hline \multicolumn{9}{|l|}{$\begin{array}{l}\text { C. albicans } \\
\text { (ATCC } 90028 \text { ) }\end{array}$} \\
\hline $1 \mathrm{~min}$ & $(-)$ & 2.12 & $(-)$ & 2.56 & $(-)$ & 2.39 & $(-)$ & 2.71 \\
\hline $5 \mathrm{~min}$ & $(-)$ & 2.70 & $(-)$ & 2.28 & $(-)$ & 2.62 & $(-)$ & 2.56 \\
\hline $10 \mathrm{~min}$ & $(-)$ & 2.51 & $(-)$ & 2.00 & $(-)$ & 2.70 & $(-)$ & 2.35 \\
\hline $15 \mathrm{~min}$ & $(-)$ & 2.36 & $(-)$ & 2.71 & $(-)$ & 2.40 & $(-)$ & 2.92 \\
\hline \multicolumn{9}{|l|}{$\begin{array}{l}\text { B. subtilis } \\
\text { (ATCC 6633) }\end{array}$} \\
\hline $1 \mathrm{~min}$ & 2.24 & 3.30 & 2.43 & 2.90 & 3.06 & 3.30 & 2.35 & 3.22 \\
\hline $5 \min$ & $(-)$ & 3.17 & $(-)$ & 3.30 & $(-)$ & 3.47 & $(-)$ & 3.30 \\
\hline $10 \mathrm{~min}$ & $(-)$ & 3.15 & $(-)$ & 3.18 & $(-)$ & 3.17 & $(-)$ & 2.93 \\
\hline $15 \mathrm{~min}$ & $(-)$ & 3.25 & $(-)$ & 2.98 & $(-)$ & 3.32 & $(-)$ & 3.06 \\
\hline
\end{tabular}

${ }^{*}$ Test microorganism adhered on gpc $v s$ treatment with chlorhexidine for $1 \mathrm{~min}$.

${ }^{\dagger}$ Test: contaminated cone treated with chlorhexidine solutions.

${ }^{\ddagger}$ Positive control: contaminated cone treated with sterile saline solution containing neutralizers: $0.5 \%$ Tween 80 (Difco) and $0.07 \%$ soy lecithin (Santista Alimentos S.A.) in experiments 1-4, and without neutralizers in experiment 5.

${ }^{\S}$ No growth in tryptic soy agar (Difco) or Sabouraud modified agar (Difco).

streptococci, Bacillus subtilis, and Candida krusei, and a microbial culture obtained from an infected tooth canal. Stabholz et al. (33), demonstrated that $2 \%$ chlorhexidine in an aqueous solution effectively disinfects gpc contaminated with bacteria from the oral flora (Streptococcus mutans and Streptococcus sanguis), intestinal flora (Escherichia coli and Enterococcus faecalis), skin flora (Staphylococcus aureus), and environment (Bacillus subtilis), within 10 min. A qualitative bacteriological study carried out in our laboratory showed that a $2 \%$ chlorhexidine digluconate detergent solution eliminated in 1 
Table 2. Carryover control: Student's $t$ test of mean of difference" on recovery of Staphylococcus aureus, Enterococcus faecalis, Escherichia coli, Candida albicans cells and Bacillus subtilis spores.

\begin{tabular}{|c|c|c|c|}
\hline $\begin{array}{c}\text { Test } \\
\text { microorganisms } \\
\text { adhered on } \\
\text { gutta-percha } \\
\text { cones }^{\dagger} \text { vs } \\
\text { treatment with } \\
\text { chlorhexidine }\end{array}$ & $\begin{array}{c}\text { Carryover } \\
\text { test }^{\S}\end{array}$ & $\begin{array}{l}\text { Carryover } \\
\text { control" }\end{array}$ & $P$ - value ${ }^{\text {II }}$ \\
\hline
\end{tabular}

\begin{tabular}{|c|c|c|c|c|}
\hline \\
\hline & \\
\hline \multicolumn{5}{|c|}{$\begin{array}{l}\text { S. aureus (ATCC 6538) } \\
\text { Dentsply } \\
\text { Aaueous }\end{array}$} \\
\hline \multicolumn{5}{|c|}{ Detergent $\quad 6.02 \pm 0.19$} \\
\hline \multicolumn{5}{|l|}{ Hygenic ® } \\
\hline \multirow{2}{*}{$\begin{array}{l}\text { Aqueous } \\
\text { Detergent }\end{array}$} & $6.00 \pm 0.31$ & $5.99 \pm 0.11$ & 0.11189 & \multirow{2}{*}{$\begin{array}{l}0.91441 \\
0.84558\end{array}$} \\
\hline & $5.99 \pm 0.12$ & $6.01 \pm 0.07$ & 0.19987 & \\
\hline
\end{tabular}

E. faecalis (ATCC 29212)

Dentsply®

Aqueous

Detergent

$5.50 \pm 0.18$

$5.53 \pm 0.19$

0.25111

0.806817

0.332498

Hygenic ${ }^{\circledR}$

$5.30 \pm 0.49 \quad 5.57 \pm 0.41 \quad 1.01839$

0.160908

Aqueous

$4.99 \pm 0.09 \quad 5.41 \pm 0.62 \quad 1.63258$

0.883273

Detergent

$5.59 \pm 0.25$

$5.61 \pm 0.17$

0.15062

E. coli (ATCC 25922)

\section{Dentsply®}

Aqueous

Detergent

$5.63 \pm 0.04$

$5.49 \pm 0.17$

2.06502

0.089072

Hygenic®

$5.89 \pm 0.23$

$5.58 \pm 0.19$

0.74432

0.473812

Aqueous

$5.58 \pm 0.17$

$5.59 \pm 0.09$

0.22912

0.823396

Detergent

$6.39 \pm 0.37$

$6.40 \pm 0.31$

0.04202

0.967307

\section{C. albicans}

\section{Aqueous}

Detergent

$3.58 \pm 0.36$

$3.56 \pm 0.46$

0.11133

0.913558

0.470280

Hygenic®

$3.36 \pm 0.34$

$3.52 \pm 0.37$

0.75044

0.112080

Aqueous

$3.44 \pm 0.09$

$3.34 \pm 0.11 \quad 1.74223$

$3.56 \pm 0.30 \quad 0.75260$

0.483614

\section{B. subtilis (ATCC 6633)}

\section{Dentsply®}

Aqueous

Detergent

$3.19 \pm 0.26$

$3.40 \pm 0.16$

1.65550

0.128919

$3.09 \pm 0.13$

$3.11 \pm 0.17$

0.26929

0.793181

Hygenic®

Aqueous

$3.49 \pm 0.25$

$3.26 \pm 0.27$

1.48208

0.169129

Detergent
$3.11 \pm 0.23 \quad 0.16911$ min vegetative cells of $S$. aureus, E. coli, and E. faecalis and spores of B. subtilis (ATCC 6633) adhered on the surface of gpc (6).

On the other hand, Siqueira et al. (31) reported that a $2 \%$ chlorhexidine digluconate solution showed no sporicidal activity after 10 min of contact with gpc contaminated with spores of Bacillus subtilis (ATCC 19659). In study by Siqueira et al. (31), contaminated gpc were dried for 24 hours in a vacuum desiccator, and then treated for $1,3,5$, or $10 \mathrm{~min}$ with $2 \%$ chlorhexidine. Next, the cones were individually cultured and subcultured in thioglycolate broth at $37^{\circ} \mathrm{C}$ for 21 days. Gomes et al. (14), in a similar study, found that an aqueous $2 \%$ chlorhexidine gluconate solution was not effective in eliminating B. subtilis (ATCC 19659) spores adhered on gpc, even after 72 hours of contact. It is not clear whether the contrast of these results with those reported in our study is due to differences in study design, use of a different strain of B. subtilis as test microorganism, or the formulation dependence of the chlorhexidine. Further microbiological and clinical studies are needed to explain these contradictory findings.

However, in endodontic practice the natural contamination of the gpc consists mainly of vegetative bacteria rather than resistant bacterial spores (12). On the other hand, bacterial spores might be infrequent on clean, non-used gpc (31).

In endodontic practice, the sporostatic and microbicidal activity of chlorhexidine can be significantly increased by the use of paste and cement obturators that show antimicrobial activity $(2,11)$. The antimicrobial action of the gpc, particularly attributed to the zinc oxide, can also contribute to decontaminate the radicular channel (25).

Gutta-percha cones are the current material of choice for root canal obturation $(7,9,18)$. However, their chemical composition is not standardized by the different manufacturers. For example, three studies of the chemical composition of 20 brands of commercially available guttapercha cones showed great heterogeneity. The following percentages of chemical components were found: $15-22 \%$ gutta-percha (matrix), 37-84\% zinc oxide (filler), 0-31\% barium sulphate (radiopacifier), and 1-4\% waxes and resins, or both (plasticizer) $(13,15,20)$. The results obtained in our study suggest that the possible differences in the commercial formulations of the Brazilian (Dentsply ${ }^{\circledR}$ ) and American (Hygenic ${ }^{\circledR}$ ) gpc seem not to have influenced their decontamination with the aqueous or detergent solutions of $2 \%$ chlorhexidine digluconate.

In microbiological assays with antiseptics, a fundamental step is the elimination of possible residual inhibitory activity caused by the transference of antiseptic to the culture medium, resulting in a false-negative test (23). This could in practice be attained by using neutralization, dilution, and

* Results $\left(\log _{10}\right)$ of the mean of two determinations of the number of recoverable CFUs per milliliter. Counts were performed in triplicate by the drop-counting technique (Miles et al. 1938); Gutta-percha cones: Dentsply® and Hygenic ${ }^{\circledR}$; Aqueous solution of $2 \%$ digluconate chlorhexidine; detergent solution of $2 \%$ digluconate chlorhexidine; ${ }^{\S}$ Contaminated cone plus chlorhexidine solutions-treated cone; "Contaminated cone treated with sterile saline solution; " ${ }^{\pi}$ Not significant at $P>.05$. 
washing techniques (8). The results shown in Table 2 clearly demonstrated the efficacy of the neutralization (experiments 14) and dilution (experiment 5) techniques used in our study, with similar recovery of the test microorganisms in both controls and carryover tubes $(P>.05)$. In experiment 5 , we used the dilution technique because the neutralizer agents interfered with the development of $B$. subtilis spores.

In our study, the $S$. aureus, E. faecalis, E. coli, and $C$. albicans strains were chosen because these microorganisms are frequently isolated from infected root canals $(32,37)$. They are classic representatives of facultative aerobic gram-positive (S. aureus, E. faecalis) and gram-negative (E. coli) bacteria, and yeasts ( $C$. albicans). Additionally, the $B$. subtilis spore suspension was used because the spores are highly resistant to physical and chemical sterilizing agents. A limitation of our study was that anaerobic bacteria were not included, despite their well-recognized role in the etiology of endodontic infections $(32,36)$.

The results obtained under the experimental conditions of this study demonstrated that both aqueous and detergent solutions of $2 \%$ digluconate chlorhexidine were effective in decontaminating gpc in $5 \mathrm{~min}$. The results also suggest that the possible differences in the chemical composition of the gpc from two different manufacturers seem not to have influenced their decontamination by chlorhexidine solutions.

In summary, the results suggest the use of $2 \%$ chlorhexidine during 5 minutes for the decontamination of gutta-percha cones in endodontic practice.

\section{ACKNOWLEDGEMENTS}

This work was supported in part by the Coordenação de Aperfeiçoamento do Pessoal de Ensino Superior (CAPESBrazil). R.R. held a scholarship from CAPES-Brazil.

We thank Dr. Janet W. Reid for revising the English text.

\section{RESUMO}

\section{Descontaminação de cones de guta-percha com clorexidina}

No presente estudo foi investigada a eficácia das soluções aquosa e detergente de digluconato de clorexidina a $2 \%$ na descontaminação de cones de guta-percha (cgp) contaminados experimentalmente com bactérias, leveduras ou esporos bacterianos. Os cones foram contaminados com $10^{7}$ a $10^{8}$ unidades formadores de colônias por mililitro (ufc/ml) dos seguintes microrganismos teste: Staphylococcus aureus, Enterococcus faecalis, Escherichia coli, ou Candida albicans. Esporos de Bacillus subtilis foram também testados. Os cones contaminados foram tratados com as soluções de clorexidina por, respectivamente, 1, 5, 10 ou 15 min. Cada cone foi então transferido para solução salina e homogeneizado para a determinação das ufc dos microorganismos. As soluções de clorexidina destruíram em 1 min as células de $S$. aureus, $E$. faecalis ou de C. albicans aderidas à superfície dos cgp. E. coli foi eliminada em 5 min com a solução detergente. Os esporos de Bacillus subtilis foram eliminados pelas soluções de clorexidina em 5 min. Os resultados deste estudo demonstraram que as soluções aquosa e detergente de clorexidina a $2 \%$ foram efetivas na descontaminação dos cones de guta percha em 5 minutos.

Palavras-cahve: Clorexidina, descontaminação, cones de guta-percha

\section{REFERENCES}

1. Ayliffe, G.A.J.; Babb, J.R.; Quoraishi, A.H. (1978). A test for hygienic hand disinfection. J. Clin. Pathol., 31, 923-928.

2. Al-Khatib, Z.Z.; Baum, R.H.; Morse, D.R.; Yesilsoy, C.; Bhambhani, S.; Furst, M.L. (1990). The antimicrobial effect of various endodontic sealers. Oral Surg. Oral Med. Oral Pathol. Oral Radiol. Endod., 70, 784-790.

3. Babb, J.R.; Davies, J.G.; Ayliffe, G.A.J. (1991). A test procedure for evaluating surgical hand disinfection. J. Hosp. Infect., 18 (Suppl. B), 41-49.

4. Cardoso, C.L.; Kotaka, C.R.; Guilhermetti, M.; Hidalgo, M.M. (1998). Rapid sterilization of gutta-percha cones with glutaraldehyde. $J$. Endod., 24, 561-563.

5. Cardoso, C.L.; Kotaka, C.R.; Redmerski, R; Guilhermetti, M.; Queiroz, A.A. (1999). Rapid decontamination of gutta-percha cones with sodium hypochlorite. J. Endod., 25, 498-501.

6. Cardoso, C.L.; Redmerski, R.; Bittencourt, N.L.R.; Kotaka, C.R. (2000). Effectiveness of different chemical agents in rapid decontamination of gutta-percha cones. Braz. J. Microbiol., 31, 6771.

7. Cohen, S.; Burns, R.C. (1994). Pathways of the pulp., Mosby, St. Louis.

8. Crémieux, A.; Fleurette, J. (1983). Methods of testing disinfectants. In: Block, S.S. (ed). Disinfection, Sterilization and Preservation. Lea \& Febiger, Philadelphia, USA, p.918-945.

9. De Deus, Q.D. (1992). Endodontia. Editora Médica e Científica Ltda., Rio de Janeiro.

10. Doolittle, T.P.; Rubel, R.L.; Fried, I. (1975). The effectiveness of common office disinfection procedures for gutta-percha and silver points. N. Y. State Dent. J., 41, 409-414.

11. Duarte, M.A.H.; Weckwerth, P.H.; Moraes, I.G. (1997) Análise da ação antimicrobiana de cimentos e pastas empregados na prática endodôntica. Rev. Odontol. Univ. São Paulo 11, 299-305.

12. Frank, R.J.; Pelleu Jr.; G.B. (1983). Glutaraldehyde decontamination of gutta-percha cones. J. Endod., 9, 368-371.

13. Friedman, C.M.; Sandrik, J.L.; Heurer, M.A.; Rapp, G.V. (1975). Composition and mechanical properties of gutta-percha endodontic points. J. Dent. Res., 54, 921-925.

14. Gomes, B.P.F.A.; Vianna, M.E.; Matsumoto, C.U.; Silva Rossi, V.P.; Zaia, A.A.; Ferraz, C.C.R.; Souza Filho, F.J. (2005). Disinfection of gutta-percha cones with chlorhexidine and sodium hypochlorite. Oral Surg. Oral Med. Oral Pathol. Oral Radiol. Endod., 100, 512-517.

15. Gurgel-Filho, E.D.; Feitosa, J.P.A.; Teixeira, F.B.; Paula, R.C.M.; Silva Jr.; J.B.A.; Souza-Filho, F.J. (2003). Chemical and X-ray analyses of five brands of dental gutta-percha cone. Int. Endod. J., 36, 302-307.

16. Larson, E. (1995). APIC guidelines for handwashing and hand antisepsis in health care settings. Amer. J. Infect. Control, 23, 251269. 
17. Leonardo, M.R.; Bonifácio, K.C.; André, R.F.G.; Silva, L.A.B.; Ito, I.Y. (1997). Evaluation of the sterility and antimicrobial activity of gutta-percha cones. Braz. Endod. J., 2, 51-54.

18. Leonardo, M.R. (2005). Endodontia: Tratamento de canais radiculares. Editora Artes Médicas, São Paulo.

19. Linke, H.A.B.; Chohayeb, A.A. (1983). Effective surface sterilization of gutta-percha points. Oral Surg., 55, 73-77.

20. Marciano, M.; Michailesco, P.M. (1989). Dental gutta-percha: chemical composition, X-ray identification, enthalpic studies, and clinical implications. J. Endod., 15, 149-153.

21. McDonnell, G.; Russel, A.D. (1999). Antiseptics and disinfectants: activity, action, and resistance. Clin. Microbiol. Rev., 12, 147-179.

22. Miles, A.A.; Misra, S.S.; Irwin, J.O. (1938). The estimation of the bactericidal power of the blood. J. Hyg., 38, 732-749.

23. Miller, C.H.; Lu, D.P.; Crimmel, J.E. (1973). Bactericidal efficiency of some antimicrobial chemicals. J. Dent. Res., 52: 184.

24. Montgomery, S. (1971). Chemical decontamination of gutta-percha cones with polyvinylpyrrolidone-iodine. Oral Surg., 31, 258-266.

25. Moorer, W.R.; Genet, J.M. (1982). Antibacterial activity of guttapercha cones attributed to the zinc oxide component. Oral Surg., 53, 508-517.

26. Russel, A.D.; Ahonkhai, I.; Rogers, D.T. Microbiological applications of the inactivation of antibiotics and other antimicrobial agents. (1979). J. Appl. Microbiol., 46, 207-245.

27. Russel, A.D. (1986) Chlorhexidine: antibacterial action and bacterial resistance. Infection, 14, 212-215.
28. Russel, A.D. Bacterial spores and chemical sporicidal agents. (1990) Clin. Microbiol. Rev., 3, 99-119.

29. Senia, A.E.S.; Marraro, R.V.; Mitchell, J.L.; Lewis, A.G.; Thomas, L. (1975). Rapid sterilization of gutta-percha cones with $5.25 \%$ sodium hypochlorite. J. Endod., 1, 136-140.

30. Shaker, L.A.; Furr, J.R.; Russel, A.D. (1988). Mechanism of resistance of Bacillus subtilis spores to chlorhexidine. J. Appl. Bacteriol., 64, 531-539.

31. Siqueira Jr., J.F.; Pereira da Silva, C.H.F.; Cerqueira, M.D.O.; Lopes, H.P.; Uzeda, M. (1998). Effectiveness of four chemical solutions in eliminating Bacillus subtilis spores on gutta-percha cones. Endod. Dent. Traumatol., 14, 124-26.

32. Siqueira Jr., J.F. (2002). Endodontic infections: concepts, paradigms, and perspectives. Oral Surg. Oral Med. Oral Pathol. Oral Radiol. Endod., 94, 281-293.

33. Stabholz, A.; Stabholz, A.; Friedman, S.; Helling, I.; Sela, M.N. (1997). Efficiency of different chemical agents in decontamination of guttapercha cones. Int. Endod. J., 20, 211-216.

34. Stella, S.R.B.R. (1995). Produção e controle de qualidade de indicadores biológicos para esterilização a vapor. Rev. Bras. Anal. Clin., 27, 31-36.

35. Suchde, R.V.; Talim, S.T.; Billimoria, K.F. (1970). Efficiency of cold sterilizing agent for endodontic procedure. J. Dent. Res., 58, 670.

36. Sundqvist, G. (1994). Taxonomy, ecology, and pathogenicity of the root canal flora. Oral Surg., Oral Med. Oral Pathol., 78: 522-530.

37. Tronstad, L. (1992). Recent development in endodontic research. Scand. J. D. Res., 100, 52-59. 